\title{
The Place of the Supplementary Health Personnel in the Medical Team
}

\begin{abstract}
(Presidential Address to the Annual General Meeting of Western Province Branch S.A.S.P., 23rd June, 1966).
\end{abstract}
By Professor B. BROMILOW-DOWNING,

University of Cape Town, President Western Province Branch, Vice-Chairman S.A.S.P.

Madam Chair, Ladies and Gentlemen, last year on an occasion similar to this I was indiscreet enough to say that the term "presidential address" was so resounding that it seemed as though adequate preparation and research was required of me to give a formal address. I was indiscreet enough to say that if such was expected of me then I would require adequate notice to prepare such an address. The relevant minute of the last Annual General Meeting reads:

"Professor B. Bromilow-Downing before he started to give his address, commented that the title "Presidential Address" was rather grandiose as it really entailed an address of about three-quarters of an hour duration and which could be published in a journal".

Thus I should have realised what was expected of me when I was asked some six or so weeks ago as to what night would suit me for the Annual General Meeting and what subject I would choose for my presidential address. On the spur of the moment and without thinking I gave the title "The place of the Supplementary Health Personnel in the Medical Team" because at that time the problem happened to be occupying my mind in a rather specific way. I still thought I might be able to get away with some sort of extempore, off the cuff expression of opinion on this very controversial subject. But you, Madam Chair, left me in no doubt as to what was expected of me in a recent interview. You more or less said to me "you wanted adequate notice, you have had it, now we expect a presidential address". I will do my best; it will last thirty minutes. The subject "The place of the Supplementary Health Personnel in the Medical Team" when I came to look into it is so wide that had I given it more thought before announcing it as the title of my address I would have been intimidated to the extent of abandoning the project but having given you the title I had to proceed. I have been greatly stimulated by my investigations and wish I had left myself more time to go into the subject in depth. In expressing these opinions I trust that you will accept that these are my personal views. By the very nature of the position I hold I have to wear many hats. Some of them directly through my office and others, for example, the office of Honorary President of the Cape Western Branch of the South African Society of Physiotherapy and the National Honorary Vice-Presidency of that organisation, I hold indirectly through my personal interests

But tonight I want you to regard me as standing before you completely hatless and my sparsely covered pate exposed entirely to the elements. I speak as myself, expressing my own thoughts gathered after many years of interest, by chance, in the so called "auxilliaries" but now styled Supplementary Health Services. The chance that I refer to is that firstly I have a family interest in optometry, (optometrists used to be called opticians). Secondly in the immediate post World War II years as the superintendent of a large provincial hospital I was confronted with the eternal shortage of "auxillary" staff. There was only one answer and that was to train them ourselves thus I became interested in the training of radiographers, (diagnostic and therapeutic) and medical technologists and was instrumental in introducing courses in these professions in the Eastern Cape. Thirdly, immediately on the assumption of my present post I was called upon to implement the training of Physiotherapists and Sister Tutors in a university. Had I had the experience at that time which I have today, I do not think I would have had the temerity to even attempt the introduction of these courses in an institution such as ours which is devoted and dedicated to the highest standards of academic learning and sometimes looks askance at vocational training, even of medical practitioners. But I am glad that I came in at that stage of my career because I am now convinced that a high standard of academic learning is the greatest and soundest background to what the purist academicians call vocational training. Fourthly, again by chance I was elected to the committee on the Medical Council which deals with the Supplementary Health Services and fifthly again, by chance, with the efflux of time I was elected Chairman of that committee. My rather wide background now stands me in good stead.

You would think that in my position it would be easy for me to define exactly what is meant by Supplementary Health Services. It is only when I came to prepare this paper that I found myself in need of such a definition.

I knew that our own Act, the South African Medical, Dental and Pharmacy Act of 1928, had made provision even forty years ago for the registration of what we now term Supplementary Health Personnel, I therefore thought it would be quite safe to look to that Act for an adequate definition. But the nearest one can say is that the scope of the Council under the Act includes all matters relating to "medical practitioners, dentists, interns, medical and dental students, masseurs, sanitary or health inspectors, food inspectors and other classes of persons concerned with the treatment or prevention of physical defects or disease in man." Our critics hold that it is questionable whether Section 32 (here paraphrased) of the Act gives the Council the right to establish and keep registers (voluntary or otherwise) for categories such as orthopaedic mechanicians, surgical appliance makers, chiropodists, dieticians, medical technologists, physiotherapists, radiographers etc. and claim that the intention was merely to register and control persons employed by public authorities charged with the enforcement of prescribed health regulations, pointing out that of the categories specifically mentioned, registers have only been established for $t w o$ classes, viz. Health Inspectors and Food Inspectors. More of this anon.

So even our own Act does not provide a clear definition.

We do know from the Act that only medical practitioners, interns and dentists who are duly registered by the Council are legally entitled to practise their profession in the Republic and South West Africa. In terms of the Act persons not registered by the Council, who "for gain, practise as medical practitioners, interns or dentists as the case may be or perform any act specially pertaining to the calling of a medical practitioner or dentist or pretend by means whatsoever hold themselves out to be medical practitioners, interns or dentists as the case may be (whether or not purporting to be registered) shall be guilty of a criminal offence and liable on conviction to a fine not exceeding R200." So you can see that it is of some importance to define who is a legitimate practitioner and where does he take his place in the health team. In days gone by a medical practitioner could perform all the acts pertaining to his art; but over the years, as man's knowledge has increased so has it become increasingly impossible for any one person to bring to his patient the full benefit of medical and other scientific knowledge. There has been an increasing number of categories "of persons concerned with the treatment or prevention of physical defects 
or disease in man". In spite of what the critics say the South african Medical Council has created and holds registers of no fewer than 19 different categories of such persons.

Categories of Supplementary Health Personncl Registered with the South African Medical and Dental Council.

\begin{tabular}{|c|c|c|c|c|c|}
\hline Category & & & & $\begin{array}{l}\text { Date of first } \\
\text { Registration }\end{array}$ & $\begin{array}{l}\text { Number on } \\
\text { Register, } 31 \text { st } \\
\text { Dec. } 1965\end{array}$ \\
\hline Chiropodists .. & . & $\ldots$ & . & 1949 & $A 4$ \\
\hline Dieticians $\quad \ldots$ & . & .. & . & 1949 & 12 \\
\hline Food Inspectors & $\ldots$ & . & . & 1946 & 45 (i) \\
\hline Health Inspectors & & . & . . & 1946 & 51 (i) \\
\hline Masseurs $\quad \cdots$ & $\because$ & .. & . & 1931 & 164 \\
\hline Medical Technolo & gists & & .. & 1950 & 483 \\
\hline Occupational The & rapis & & . & 1946 & 172 \\
\hline Optometrists & $\ldots$ & $\ldots$ & . & 1946 & 320 (ii) \\
\hline Orthopaedic Mech & Ianic & cians & . & 1949 & 95 \\
\hline Orthoptists ... & . & . & . & 1953 & 5 \\
\hline Physiotherapists & $\cdots$ & $\cdots$ & . & 1945 (iii) & 705 \\
\hline Psychologists . . & . & . & . & 1956 & 51 \\
\hline Psychometrists & . & . & . & 1957 & $4 \ldots$ \\
\hline Radiographers & $\cdots$ & $\cdots$ & . & 1945 & 5ŷ (iv) \\
\hline Diagnostíc Radic & rap & hers & . & 1953 & 269 \\
\hline Therapeutic Radic & gra & ohers & . & 1959 & 108 \\
\hline Speech Therapists & & & .. & 1951 & 106 \\
\hline Supplementary Di & agnc & stic & & & \\
\hline Radiographers & $\cdots$ & . & - & 1961 & 344 \\
\hline Remedial Gymnas & & . & .. & 1961 & 5 \\
\hline
\end{tabular}

19 Categories with a total of

3,042 on register

(i) Number has remained the same since 1952 .

(ii) One only optometrist was registered until 1959.

(iii) 17 Physiotherapists registered in 1945.

(iv) Registration of Radiographers ceased in 1958 with the introduction of the categories: Diagnostic and Therapeutic.

Thus it will be seen that the place of the "auxillary" has assumed an ever increasing importance with the passage of time. There is no doubt that today the public would be sadly bereft if the services of the supplementary health personnel were, for one reason or another, to be withdrawn. But at the same time we have to be on our guard against quackery. I have given you the provision in the Act which makes it a criminal offence for persons to engage in medical practice for gain without being registered. It is this registration which is the hallmark of Parliament and through Parliament of the people of the competency to practise their profession.

Over the last hundred years, one could almost say since the establishment of the General Medical Council of the United Kingdom, in the English speaking world this system of registration has been accepted as an indication of who shall be entitled to perform medical acts to the benefit of the patient. But do not let us be deceived into a sense of false security by believing that the concept of orthodox medicine is universally accepted even amongst the intelligensia. We cannot be complacent, sit back and think that the status achieved by the medical and allied professions must be acceptable to all. There are those who refuse to accept that the supplementary services have achieved professional status. In the endeavour to establish legislation for the protection of the public we are constantly confronted with the accusation that we are protecting our own interests. I shall never forget when the regulations for the training for the Diploma of Physiotherapy at our own University were first introduced exception was taken to the declaration which is required of each of our diplomates, namely:

"I, A.B., solemnly declare that, as a physiotherapist holding the diploma in physiotherapy of the University of Cape Town, I will not undertake any treatment except under the direction of a registered Medical Practitioner; that I will exercise my profession to the best of my knowledge and ability for the good of all persons whose health may be placed in my care, and for the public weal; that I will hold in due regard the honourable traditions and obligations of the profession of physiotherapy, and will do nothing inconsistent therewith; and that I will be loyal to the University and endeavour to promote its welfare and maintain its reputation."

It was stated that this was a blatant attempt by the medical profession to introduce a "closed shop". As events prove, this objection was not supported, and the declaration is required of our diplomates. Throughout the ages it has been difficult to convince the public that legislation and the establishment of ethical codes are primarily in the public interest and not in the interests of the professions. It is interesting to look at the difference between ethics and etiquette. So often these two terms are hopelessly confused; medical ethics, medical etiquette. Medical ethics we find is a reference to duty, what ought to be done, the right thing, the proper thing, the decent thing, the inescapable duty, the obligation (shall we say to the public?). When we look at etiquette it is conformity, traditionalism, . orthodoxism, formalism; that is being fashionable. When we speak of ethics we speak of our duty, and our duty is primarily to our patient and through our patient to the public and through the public to our own professions.

It is difficult to legislate for crooks but all the enactments that one has come across are primarily devised for the protection of the public against their own gullibility, to protect them from the blandishments of persons whose ethical standards, that is whose ideas of duty and obligation, may not be all that should be desired. There are many people both professional and lay who find it difficult to distinguish between physiotherapy and chiropraxy and it is only by the maintenance of the highest ethical standards, the strict obedience to scientific principle and precept that will result in the clear definition of the profession as against the quack. If the so called quacks maintain that discipline to scientific fact and precept then they will emerge from the darkness of quackery and be recognised as professions. Make no mistake the distinction between quack and profession is very fine. Our legislators, with all their farsightedness, have made it extremely difficult to secure a conviction in a criminal court of this very section which I have twice before quoted. The freedom of the individual still is paramount. And after more than a hundred years of legislative control quackery, or what we term quackery, still prevails.

The extension of this legislation to provide for compulsory registration of supplementary health personnel and thereby distinguish quack from profession is becoming a hardy annual. Year after year I have told you of the attempts made to make registration of supplementary health personnel compulsory. Your society since 1927 has likewise been concerned in the same effort for it was in that year that members of Parliament and the Minister of Health were interviewed by your three founder members in an attempt to obtain registration for masseurs, as you were then known, with the South African Medical and Dental Council under the proposed Act of 1928. As you all know your founders succeeded in establishing the principle of registration albeit on a voluntary basis. Endeavours to extend the voluntary registration under the Act to compulsory registration has thus far proved unavailing. Believing that medical treatment should be regarded as a whole, every endeavour has been made to keep this under the Medical, Dental and Pharmacy Act. This concept of holism has not been followed in other countries, In the United Kingdom, for instance, they have the Opticians Act of 1958 and the Professions Supplementary to Medicine Act of 1960 , to name but two. These acts together with the legislation providing for a General Dental Council as well as a General Medical Council in addition to the Nursing Council and Midwifery Council, has indeed fragmented the medical administrative control in the United Kingdom. I do trust that we in this country will not be tempted into the establishment of a multitude of councils and the fragmen- 
tation of the control of "persons concerned with the treatment or prevention of physical defects or disease in man". Personally I feel that with the establishmnet of the Nursing Council we have gone far enough.

Earlier I mentioned the difficulties I have in definition of acts pertaining to supplementary health personnel. I am amused and envious of the provisions within the Opticians Act which simply states "a person who is not a registered medical practitioner or a registered ophthalmic optician"shall not test the sight of another person. It would be indeed a happy day if we could make a similar provision within the field of physiotherapy and other supplementary health personnel. It would be indeed a happy day if the functions of all supplementary health personnel could be so clearly defined.

In general when we look to these persons "concerned in the treatment or prevention of physical defects or disease in man" with the 19 different categories recognised in this country we must appreciate the fact that each category is becoming specialised in its respective place within the medical team. As in all teams there must be a captain, someone who takes decisions (right or wrong) and who assumes the final and ultimate responsibility. I am always impressed by the efficiency and precision of the working within a sea going vessel. The cook does his job, the quartermaster his, the navigating officer his and so on, but over all stands the captain ultimately responsible. He may not have the faintest idea of what is for breakfast tomorrow but should the crew be dissatisfied it is the captain who will be asked to explain. In the same way the General Officer commanding a vast army may not know how to fire a twenty-five pounder gun but he knows the advantage of the concentration of fire at a particular moment and expects the fire to be maintained when he gives the order. At the same time he would be most unwise if he were not sure that his gunnery officers were adequately trained and that there were sufficient ammunition available to enable his order to be carried out. You can see where I am leading, that the captain of the ship with his ultimate responsibility, the general officer commanding an army with his ultimate responsibility can be likened to the position of a medical practitioner of modern times with his responsibility over the patient as a whole. He may not know how to perform the acts of a medical technologist or that of a diagnostic radiographer or that of the physiotherapist but he should know the part that each one is to play in the ultimate care of his patient. It is becoming increasingly difficult to make medical practitioners aware of the immense and varied potentialities of the supplementary health professions. I am frequently taken to one side and advised to include more of this or that in the teaching of medical students. Unfortunately it is difficult to get many medical practitioners to recognise the so called auxillaries now as having evolved to professions of their own. But by the same token one must preach a word of warning to the supplementary health professions not to try and assume the position of the captain, but rather to ensure that the captain is fully cognizant of the potentialities of his crew and by using them to the fullest of their ability and taking such advice as he may deem fit, provide a smooth and safe passage for his patients under his over all direction. The current strike of seamen in the United Kingdom demonstrates the dangers when things go awry between management and crew. I personally have sufficient confidence in both the captain and the crew within the medical profession to be sure that a similar situation will never arise between our professions but that we shall always together place our patients' interests above those of personal interests or professional status, and continue to function as a team working in close co-operation and mutual respect.

I trust that we will all endorse the view expressed by the Editor of the Lancet in the final paragraph of his paper "The Greater Medical Profession": "The unanswerable reason why we should accept the so called auxiliaries as members of the greater medical profession, and welcome them as colleagues, is that we want them to go on sharing with us that very difficult, but very important professional code according to which the patients interests come first. In a service which, after all, exists solely for patients, this code is as valid for the radiographer and the records officer as it is for the surgeon: they should equally accept, for example, the obligation to respect professional confidence. We have a great tradition, and we have a duty to pass it on to all our associates who will accept it. Though the practice of medicine now depends on so many who never went through our schools, the vittue need not, and must not go out of it".

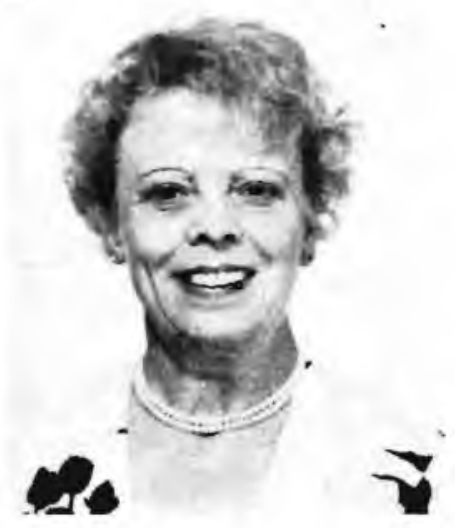

Miss Mariorie McDowell, M.C.S.P.

Miss Marjorie McDowell whose article on "Physiotherapy in Chest Conditions" appears in this Journal has recently toured South Africa visiting all the major centres, lecturing and teaching both graduates and students.

She trained at King's College Hospital in the early days of the war, being evacuated to Horton Hospital at Epsom where there was a combined Chest Unit of all the major London Hospitals. It was here she first became interested in "chests" and was always trying to get as many chest patients as possible to treat

Later Miss McDowell gained general experience at University College Hospital, London and in 1946 she went to Brompton Hospital for Chest Diseases in London, where she has been on and off ever since. During her early training at Brompton she was fortunate to be under Miss Winifred Linton who started all the work in chest physiotherapy.

In 1948 Miss McDowell trained students in a Chest Unit at the Hospital St. Pierre in Brussels and in 1951 spent some months in South Africa and Rhodesia on holiday and lecturing in Salisbury, Bulawayo, Johannesburg, Durban and Cape Town. This visit tempted Miss McDowell to visit our part of the world again in 1966.

In the interval Miss McDowell travelled a great deal training students and teaching physiotherapy for chests. In Ceylon in 1954-56 she did T.B. work where that disease was particularly rife at the time and incidently followed Miss Margaret White who is now teaching in Cape Town.

After a short spell in London Miss McDowell was off again, this time to Egypt. There she hoped to train students for T.B. work, but though she was there a year she had few students in training but much chest work to be done.

After her recent visit to South Africa Miss McDowell is now back in Brompton part-time to help train students who come from St. Mary's Hospital for six weeks at a time in their final year and to help with new staff and post graduate courses from time to time.

Miss McDowell is certainly one who has made use of her profession to see the world and before long we can expect to hear of her travels once more-possibly back to South Africa. 